\title{
Rapidly progressive glomerulonephritis in a child with Henoch-Schönlein Vasculitis and familial Mediterranean fever Betul Sozeri*1, Sevgi Mir ${ }^{1}$, Pelin Ertan ${ }^{2}$, Orhan Deniz Kara ${ }^{1}$ and Sait Sen ${ }^{3}$
}

\author{
Address: ${ }^{1}$ Department of Pediatric Nephrology, Faculty of Medicine, Ege University, Izmir, Turkey, ${ }^{2}$ Department of Pediatric Nephrology, Faculty \\ of Medicine, Celal Bayar University, Manisa, Turkey and ${ }^{3}$ Department of Pathology, Faculty of Medicine, Ege University, Izmir, Turkey \\ Email: Betul Sozeri* - betulsozeri@yahoo.com; Sevgi Mir - sevgi.mir@ege.edu.tr; Pelin Ertan - peliertan@hotmail.com; \\ Orhan Deniz Kara - orhandenizkara@hotmail.com; Sait Sen - sait.sen@ege.edu.tr \\ * Corresponding author
}

Published: 7 May 2009

Pediatric Rheumatology 2009, 7:8 doi:10.1186/1546-0096-7-8

This article is available from: http://www.ped-rheum.com/content/7///8

(C) 2009 Sozeri et al; licensee BioMed Central Ltd.

This is an Open Access article distributed under the terms of the Creative Commons Attribution License (http://creativecommons.org/licenses/by/2.0), which permits unrestricted use, distribution, and reproduction in any medium, provided the original work is properly cited.
Received: 4 November 2008

Accepted: 7 May 2009

\begin{abstract}
Henoch-Schonlein Vasculitis (HSV) is systemic small vessel vasculitis involving the skin, kidney, joints, and gastrointestinal tract. The proportion of patients reported to have renal involvement varies between $20 \%$ and $80 \%$. Rapidly progressive glomerulonephritis (RPGN)is rare syndrome in children, characterized by clinical features of glomerulonephritis (GN) and rapid loss of renal function. We present a severe kidney involvement in a 14 year old boy with HSV in who is carring MEFV mutation. A 14 year old boy had developed sudden onset of palpable purpuric rash on his extensor surfaces of lower extremities. He had elevated an erythrocyte sedimentation rate (ESR) $(45 \mathrm{~mm} / \mathrm{h})$, C-reactive protein $(3.74 \mathrm{mg} / \mathrm{dl})$, serum urea $66 \mathrm{mg} / \mathrm{dl}$, serum creatinine $\mathrm{I} .8 \mathrm{mg} / \mathrm{dl}$. Also, he had hypocomplementemia. Antinuclear antibody, anti ds DNA, antineutrophil cytoplasmic antibody, anticardiolipine antibodies were negative. Urinalysis revealed macroscopic hematuria and proteinuria with a 24-h urinary protein excretion of $55 \mathrm{mg} / \mathrm{m} 2 / \mathrm{h}$. The renal biopsy specimen showed crescentic and necrotizing glomerulonephritis. He had also M694V/EI48Q compound heterozygote mutation. Clinical symptoms and renal failure resolved with intermittant hemodialysis and medical therapy.
\end{abstract}

\section{Background}

Henoch-Schönlein Vasculitis (HSV) is systemic small vessel vasculitis involving the skin, kidney, joints, and gastrointestinal tract. The annual incidence of HSV is 22 per 100000. The pathogenesis of HSV remains unknown; however, HSV is generally believed to be immune complex-mediated disease characterized by the presence of polymeric IgA1-containing immune complexes predominantly in dermal, gastrointestinal and glomeruler capillaries $[1,2]$.

The proportion of patients reported to have renal involvement varies between $20 \%$ and $80 \%$ [3-5]. In $80 \%$ of chil- dren with a urinary abnormality, the first abnormality is detected within 4 weeks of onset of the illness [6]. Hematuria may occasionally be the initial feature. Common urinary abnormalities are albuminuria and microscopic hematuria. A smaller number of patients have macroscopic hematuria. Acute nephritic syndrome occurs in more severe cases and may lead to nephrotic syndrome or to renal insufficiency $[6,7]$.

Rapidly progressive glomerulonephritis (RPGN) is rare syndrome in children, characterized by clinical features of glomerulonephritis (GN) and rapid loss of renal function [8]. This clinical course may be seen in any form of GN 
including poststreptococcal glomerulonephritis, renal vasculitis, HSV.

It has been reported that certain vasculitides such as HSV and polyarteritis nodosa (PAN) are more frequent among familial Mediterranean fever (FMF) patients [9-14].

We present a severe kidney involvement in a 14 year old boy with HSV in who carries MEFV mutation.

\section{Case presentation}

A 14 year old boy was referred to hospital with 2 days history of back and calf pain. He had developed sudden onset of palpable purpuric rash on his extensor surfaces of lower extremities especially bilateral ankles on admission. There was no history of recent drug exposure, immunization, or upper respiratory tract infection. He denied recurrent attacks of abdominal pain and fever. Family history for FMF was negative. Physical examination showed a temperature of $38.3^{\circ} \mathrm{C}$, respiratory rate of $48 / \mathrm{min}$, pulse rate $128 / \mathrm{min}$. He was hypertensive at $140 / 100 \mathrm{mmHg}$. In auscultation, lungs were clear and the heart sounds were normal. Abdominal palpation was normal. There were symmetric palpable purpuric rash on his lower extremities.

Laboratory tests showed an erythrocyte sedimentation rate (ESR) of $45 \mathrm{~mm} / \mathrm{h}$ (normal: $<20 \mathrm{~mm} / \mathrm{h}$ ), C-reactive protein of $3.74 \mathrm{mg} / \mathrm{dl}$ (normal: $<0.3 \mathrm{mg} / \mathrm{dl}$ ), hemoglobin $10.7 \mathrm{~g} / \mathrm{dl}$, hematocrit $32.3 \%$, white blood cell count (WBC) $11900 / \mathrm{mm} 3$ with normal differential count, platelet count $340000 / \mathrm{mm} 3$, serum urea $66 \mathrm{mg} / \mathrm{dl}$, serum creatinine $1.8 \mathrm{mg} / \mathrm{dl}$, albumine $3.5 \mathrm{~g} / \mathrm{dl}$, total cholesterol 106 $\mathrm{mg} / \mathrm{dl}$, triglycerides $57 \mathrm{mg} / \mathrm{dl}$, calcium $8.7 \mathrm{mg} / \mathrm{dl}$, sodium $140 \mathrm{mEq} / \mathrm{L}$, potassium $4.7 \mathrm{mEq} / \mathrm{L}$, chloride $107 \mathrm{mEq} / \mathrm{L}$, alanine aminotransferase $23 \mathrm{U} / \mathrm{l}$, aspartate aminotransferase $16 \mathrm{U} / \mathrm{l}$. Serum complement-3 (C3) and complement-4 (C4) were decreased $(85.4 \mathrm{mg} / \mathrm{dl}, 6.6 \mathrm{mg} / \mathrm{dl}$, respectively). Serum immunglobulin (Ig) levels were normal. The anti-streptolysin - O titer was 100 Todd unit and throat culture was negative for group A $B$-hemolytic streptococcus. Antinuclear antibody, anti ds DNA, antineutrophil cytoplasmic antibody, anticardiolipine antibodies were negative. Urinalysis revealed macroscopic hematuria and proteinuria with a 24-h urinary protein excretion of $55 \mathrm{mg} / \mathrm{m} 2 / \mathrm{h}$. The fecal occult blood testing was positive. Renal ultrasonography (US) showed increased echogenicity (grade 2) in bilateral kidneys. A skin biopsy showed a leucytoclastic vasculitis and deposition of IgA. Renal doppler US was normal. Renal magnetic resonance angiography (MRA) to rule out PAN revealed normal results. Based on these clinical findings, the patient was diagnosed as having HSV with renal, skin and probable gastrointestinal tract involvement. A diagnosis of FMF was suspected because of the absence of occult blood in the stool and normal mesenteric MRA. Since there are reports of increase frequency of MEFV mutation in patients with HSV, we performed DNA analysis in our patient and found that he was compound heterozygote, carrying M694V/E148Q.

On the second day of hospitalization, He had periorbital and pitting pretibial edema. Respiratory examination revealed bibasilar crackles. His urine output decreased from 1.1 to $0.6 \mathrm{cc} / \mathrm{kg} / \mathrm{h}$ and serum urea and creatine levels were increased $(105 \mathrm{mg} / \mathrm{dl}, 3.5 \mathrm{mg} / \mathrm{dl}$, respectively). We showed that serum urea and creatinine levels in figure 1. Echocardiography showed pericardial effusion $(3 \mathrm{~mm})$, minimal mitral regurgitation and increased inferior vena cava index and inferior vena cava collapsibility index.
A

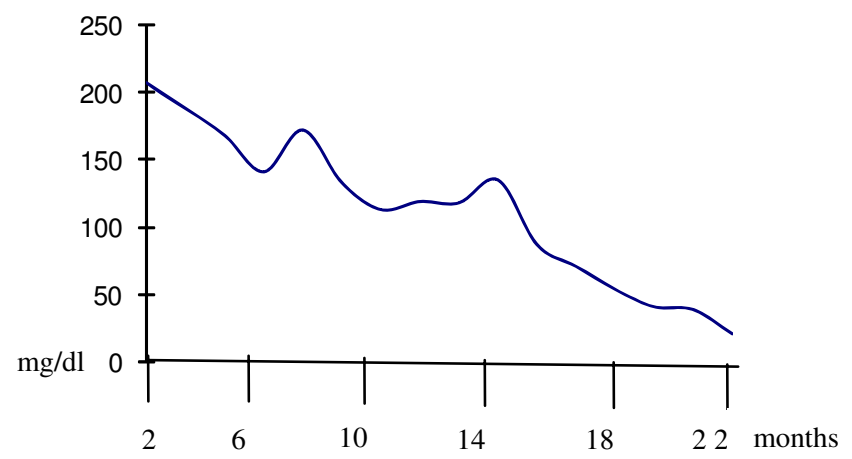

B

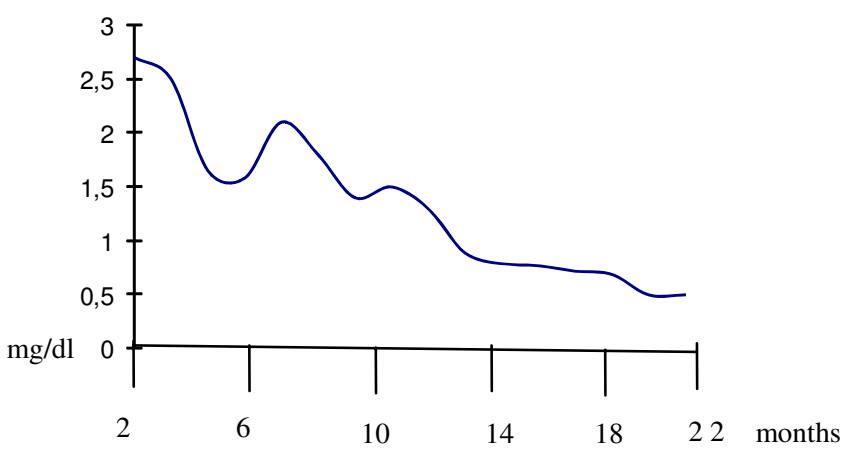

Figure I

Serum urea levels (A) and creatinine levels (B). 
The renal biopsy specimen consists of two portions of renal cortex and medulla. Forty glomeruli and many arteries are available for examination on multiple sections. The glomeruli are not significantly enlarged. They show variable, mostly segmental, expansion of the mesangial matrix associated with mild segmental mesangial hypercellularity. $25-30 \%$ of 40 glomeruli show crescents and/or necrotizing lesions (figure 2). Another glomeruli show neutrophilic infiltration five glomeruli are available for examination by immunofluorescence. The mesangium contains peripheral membranous granular deposits of IgG $(2+), \operatorname{IgA}(3+), \mathrm{C} 3(3+)$.

On the fifth day at hospitalization, hemodialysis was initiated for treatment of RPGN. Intravenous pulse methlyprednisolone was given $(30 \mathrm{mg} / \mathrm{kg}$, six consecutive days), followed by oral prednisolone and cyclophosphamide $(2 \mathrm{mg} / \mathrm{kg} /$ day $)$ for crescentic and necrotizing glomerulonephritis, in addition to Colchicine for FMF.

Clinical symptoms and renal failure resolved with intermittent hemodialysis therapy (total 20 cycles, twice a week). On one and half month after hospitalization, his abnormal serum and urinary findings resolved.

\section{Discussion}

Henoch-Schönlein Vasculitis (HSV) is the most common vasculitis in childhood and is characterized by a systemic leukocytoclastic angiitis, mainly affecting the small vessels of the skin, joints, gastrointestinal tract, and kidneys. Other organs, such as brain, lungs, and scrotum, may occasionally be involved. HSV usually affects children

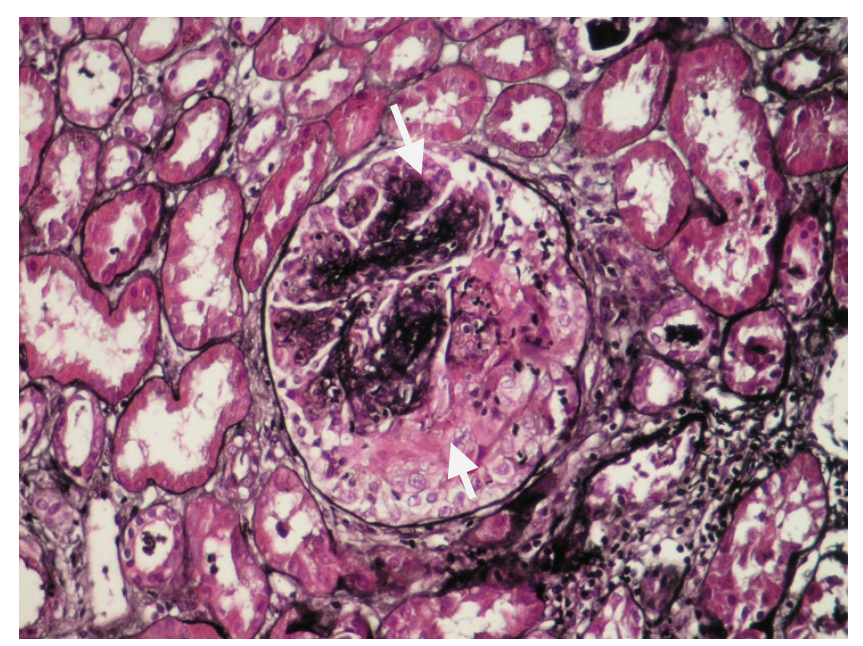

Figure 2

Segmental, expansion of the mesangial matrix and epithelial cells prolipheration and/or necrotizing lesions. between the ages of 5 and 15 years, while it is rare in adults and in infants $[15,16]$.

Renal involvement has been reported to occur in $20-80 \%$ of children with HSV; among these Henoch-Schönlein nephritis patients, $1-7 \%$ would suffer from ESRD $[4,5,17]$. It has been generally accepted that the long-term outcome is determined by the severity of renal involvement, diffuse crescentic nephritis being associated with the worst outcome [18]. A small percentage of children develop serious renal disease. Essentially, renal involvement accounts for the major morbidity of the disease. RPGN is clinical syndrome characterized by an acute nephritic illness accompanied by a rapid loss of renal function over days to weeks [19]. The histopathological correlate is the presence of cresents involving $50 \%$ or more glomeruli. RPGN may ocur in a number of conditions including postinfectious GN and HSV $[8,19,20]$.

We report a case of HSV complicated by RPGN. The presence of typical rash, severe nephritis and IgA deposits on skin and kidney biopsy confirm the diagnosis of HSV. In addition to the highly suggestive biopsy findings for HSV, negative ANCA, normal renal doppler USG, normal Renal MR angiography excluded the diagnosis of PAN.

The overall incidence of vasculitis in FMF patients is $1 \%$ of PAN and $5 \%$ of HSP, and it is significantly higher in FMF patients than in normal population [9-11,21,22].

The pathogenesis of vasculitis in patients with FMF is unknown [23]. The occurrence of circulating immune complexes in $50 \%$ of patients with FMF, complement consumption, defective inhibition of complement activation and uncontrolled release of TNF during the attacks have been described. Therefore an immune related mechanism has been suggested to be involved in the pathogenesis of FMF [24]. Immune mechanisms also play roles in FMF-associated vasculitis [24]. It is interesting to note the presence of immunoglobulins, complement C3 and fibrinogen in the skin and kidney biopsies in some of our patients.

FMF may predispose to HSV, PAN, and other forms of vasculitis, either by amplifying the inflammatory response to a subclinical insult or by predisposing to immune-mediated diseases as a consequence of immune regulations associated with FMF [25]. Further investigations of the inflammatory consequences of FMF may also help to elucidate the pathogenesis of different types of vasculitis [20].

We reported an HSV patient with RPGN whose severe course may be affected by the presence of MEFV mutation. 
We suggest that colchicine provide additive effect on his therapy.

\section{Competing interests}

The authors declare that they have no competing interests.

\section{Authors' contributions}

BS collected data, written and participated in the design study, SM: conceived of the study, and participated in its design and coordination, PE: participated in the design study and ODK: participated in the design study, SS: carried out the pathological studies. All authors read and approved the final manuscript.

\section{Consent}

Written informed consent was obtained from the patient for publication of this case report and accompanying images. A copy of the written consent is available for review by the Editor-in-Chief of this journal.

\section{References}

I. Tizard EJ: Henoch-Schönlein purpura. Arch Dis Child 1999, 80:380-383.

2. Vogler C, Eliason SC, Wood EG: Glomerular membranopathy in children with IgA nephropathy and Henoch-Schönlein purpura. Pediatr Dev Pathol 1999, 2:227-235.

3. Saulsbury FT: Epidemiology of Henoch-Schönlein purpura. Cleve Clin J Med 2002, 69:187-I89.

4. Kaku Y, Nohara K, Honda S: Renal involvement in HenochSchönlein purpura: a multivariate analysis of prognostic factors. Kidney Int 1998, 53:1755-1759.

5. Kawasaki Y, Suzuki J, Sakai N, Nemoto K, Nozawa R, Suzuki S, Suzuki $\mathrm{H}$ : Clinical and pathological features of children with Henoch-Schönlein purpura nephritis: risk factors associated with poor prognosis. Clin Nephrol 2003, 60:153-160.

6. Kawasaki Y, Suzuki H: Henoch-Schönlein Nephritis. In Comprehensive Pediatric Nephrology I st edition. Edited by: Geary DF, Schaefer F. Philadelphia, Mosby; 2008:343-35I.

7. Narchi H: Risk of long-term renal impairment and duration of follow-up recommended for Henoch-Schönlein purpura with normal or minimal urinary findings: a systematic review. Arch Dis Child 2005, 90:916-920.

8. Bagga A, Menon S: Rapidly Progressive Glomerulonephritis. In Comprehensive Pediatric Nephrology Ist edition. Edited by: Geary DF, Schaefer F. Philadelphia, Mosby; 2008:319-327.

9. Ozdogan H, Arisoy N, Kasapçapur O, Sever L, Çaliskan S, Tuzuner N, Mat C, Yazici H: Vasculitis in familial Mediterranean fever. J Rheumatol 1997, 24:323-327.

10. Akpolat T, Yilmaz E, Ozen S, Akpolat I, Danaci M, Kandemir B: M680I/M694V mutations in a patient with FMF and polyarteritis nodosa. Nephrol Dial Transplant 1998, I3:2633-2635.

II. Gershoni-Baruch R, Broza Y, Brik R: Prevalence and significance of mutations in the familial Mediterranean fever gene in Henoch-Schonlein purpura. J Pediatr 2003, I 43:658-66I.

12. Glikson M, Galun E, Schlesinger M, Cohen D, Haskel L, Rubinov A, Eliakim $M$ : Polyarteritis nodosa and familial Mediterranean fever: a report of 2 cases and review of the literature. J Rheumatol 1989, 16:536-539.

13. Braun E, Schapira D, Guralnik L, Azzam ZS: Am J Med Sci 2003, 325:363-364.

14. Cassidy JT, Petty RE: Leukocytoclastic vasculitis. In Textbook of pediatric rheumatology 4th edition. Edited by: Cassidy JT, Petty RE. New York: Churchill Livingstone; 2001:569-574.

15. Trapani S, Micheli A, Grisolia F, Resti M, Chiappini E, Falcini F, De Martino M: Henoch Schönlein purpura in childhood:epidemiological and clinical analysis of 150 cases over a 5-year period and review of literature. Semin Arthritis Rheum 2005, 35:| 43-I 53.
16. Coppo R, Mazzucco G, Cagnoli L, Lupo A, Schena FP: Long-term prognosis of Henoch-Schönlein nephritis in adults and children. Italian Group of Renal Immunopathology collaborative study on Henoch-Schnlein purpura. Nephrol Dial Transplant 1997, I 2:2277-2283.

17. Mir S, Yavascan O, Mutlubas F, Yeniay B, Sonmez F: Clinical outcome in children with Henoch-Schonlein Nephritis. Pediatr Nephrol 2007, 22:64-70.

18. Jennette JC: Rapidly progressive crescentic glomerulonephritis. Kidney Int 2003, 63: 11 64-77.

19. Morgan MD, Harper L, Williams J, Savage C: Anti-neutrophil cytoplasm-associated glomerulonephritis. J Am Soc Nephrol 2006, I 7: I 224-34.

20. Tekin M, Yalcinkaya F, Tumer N, Akar N, Misirlioglu M, Cakar N: Clinical, laboratory and molecular characteristics of children with familial Mediterranean fever-associated vasculitis. Acta Paediatr 2000, 89:177-182.

21. Bakkaloglu SA, Ekim M, Tumer N, Deda G, Erden I, Erdem T: Cerebral vasculitis in Henoch-Schonlein purpura. Nephrol Dial Transplant 2000, 15:246-248.

22. Lange-Sperandio B, Möhring K, Gutzler F, Mehls O: Variable expression of vasculitis in siblings with familial Mediterranean fever. Pediatr Nephrol 2004, 19:539-543.

23. Savi M, Asinari G, Gaudiano V, Olivetti G, Neri TM: Unusual immunologic findings in familial Mediterranean fever. Arch Intern Med 1978, I38:644-645.

24. Schlesinger M, Kopolovic J, Viskoper RJ, Ron N: A case of familial Mediterranean fever with cutaneous vasculitis and immune complex nephritis: light, electron, and immunofluorescent study of renal biopsy. Am J Clin Pathol 1983, 80:5 I I-5 I 4.

25. Sperandio BL, Möhring K, Gutzler F, Mehls O: Variable expression of vasculitis in siblings with familial Mediterranean fever. Pediatr Nephrol 2004, 19:539-543.

Publish with Bio Med Central and every scientist can read your work free of charge

"BioMed Central will be the most significant development for disseminating the results of biomedical research in our lifetime. "

Sir Paul Nurse, Cancer Research UK

Your research papers will be:

- available free of charge to the entire biomedical community

- peer reviewed and published immediately upon acceptance

- cited in PubMed and archived on PubMed Central

- yours - you keep the copyright
BiolMedcentral 